\title{
Prevalence of dental caries in dentistry students
}

\author{
Pavleova G, Vesela S, Stanko P \\ Department of Stomatology and Maxillofacial Surgery Faculty of Medicine, Comenius University and \\ St Elisabeth Hospital, Bratislava, Slovakia. gabriela.pavleova@ousa.sk
}

\begin{abstract}
The study evaluates dental caries prevalence in dentistry students. They represent a sample of individuals with good dental status, socio-economical level and access to dental care. The values of teeth number with decay and filling and values of surfaces of teeth with decay and filling indices in group with lower caries incidence give the information as to what could be achieved by systemic care and prevention of dental caries in whole population (Tab. 4. Ref. 25). Text in PDF www.elis.sk.

Key words: dental caries prevalence, dentistry students, dental caries index, DFT, DFS.
\end{abstract}

\section{Introduction}

During the past few decades, the population has polarized as to oral health level, mainly in young generation. A part of population has bad and neglected oral condition and no access to professional care caused by many different risk factors (4).

Another increasing part of population has low caries experience and good professional and home care since childhood. It could be connected also with higher socio-economic level and education of parents $(9,12,23)$.

Good representatives of this group are the sample of dentistry students in present study. The comparison of investigated dental caries indices in groups with lower and higher caries prevalence shows the difference in number of decayed and filled teeth as index DFT (number of decayed and filled teeth). This is better pronounced in the difference in index DFS (number of decayed and filled surfaces of teeth), i.e. in more decayed and filled surfaces on one tooth in group with higher caries prevalence $(3,17)$.

\section{Methods}

The study group comprises 30 young individuals aged $21-23$ years; 13 males (43.3\%), 17 females (56.7\%). Examination was provided on May 2011 to dentistry students at the Faculty of Medicine, Comenius University in Bratislava. They were characterized by good dental status and knowledge of etiology and prevention of dental caries.

Clinical examination was provided in a dental chair by one examiner with observation and probing. Assessment and recording of caries experience were done using DFT clin for decayed and filled teeth index, and DFS clin for decayed and filled teeth

Department of Stomatology and Maxillofacial Surgery Faculty of Medicine, Comenius University and St Elisabeth Hospital, Bratislava, Slovakia

Address for correspondence: G. Pavleova, MD, MPH, Department of Stomatology and Maxillofacial Surgery, Faculty of Medicine, Comenius University and St Elisabeth Hospital, Heydukova 10, SK-812 50 Bratislava, Slovakia. surfaces index. The detection of initial carious lesions was provided by bitewing radiography and calculated in index DFS RDG. Modern analytical methods in radiography were implemented (20).

According to DFS clin, individuals were divided into 2 groups; one with lower and the other with higher caries prevalence, namely in range of 0-6 and more than 7, respectively.

Dental caries risk was suggested according to bacterial salivary test followed in another study. Higher evidence of Streptococcus mutans is considered to be a risk indicator for initiation of new carious lesions (13). The average number of colony forming units (CFU) in the group with lower caries was 2.78, in range of 1.1-4.2. In the group with higher caries prevalence it was 5.08, in range of 2.1-8.1.

\section{Statistic methods}

For statistic evaluation of values differences, SPSS 16.0 software was used. Tests were done on significance level of $\alpha=0.05$.

\section{Results}

The differences in DFT and DFS values (6.77 and 12.70 total) show that there are more surface lesions. This is seen in males (6.31 and 11.92) as well as in females (7.12 and 13.29).

The values of all caries indices between males and females were not significantly different.

The values of DFS clin and DFS RDG were significantly different in total, and in both males and females ( $\mathrm{p}=0.001)$.

Individuals with higher caries prevalence have significantly higher values of DFT clin $(p<0.001)$. DFS clin $(p<0.001)$ and DFS RDG $(p<0.001)$ in comparison with individuals showing lower caries prevalence.

In higher prevalence group, the amount of caries lesions ranges from 10 to 39 while in lower prevalence group it ranges only from 0 to 6 .

The caries experience is seen in different values of DFT and DFS. In higher caries prevalence group it is 11.07 and 22.33. In lower caries prevalence group it is 2.47 and 3.07. 
Tab. 1. Study groups and dental caries indices.

\begin{tabular}{lcccc}
\hline Groups & & DFT clin. & DFS clin. & DFS RDG \\
\hline Males & $\mathrm{n}$ & 82 & 155 & 166 \\
\hline N13 & mean & 6.31 & 11.92 & 12.77 \\
\hline Females & $\mathrm{n}$ & 121 & 226 & 240 \\
\hline N17 & mean & 7.12 & 13.29 & 14.12 \\
\hline Total & $\mathrm{n}$ & 203 & 381 & 406 \\
\hline Mean & 30 & 6.77 & 12.70 & 13.59 \\
\hline
\end{tabular}

Tab. 2. Dental caries indices in groups with higher and lower caries prevalence.

\begin{tabular}{llccc}
\hline Groups & & DFT clin. & DFS clin. & DFS RDG \\
\hline \multirow{2}{*}{ Higher Prevalence } & range & $7-18$ & $10-39$ & $12-39$ \\
& $\mathrm{n}$ & 166 & 335 & 356 \\
\hline N15 & mean & 11.07 & 22.33 & 23.73 \\
\hline \multirow{2}{*}{ Lower Prevalence } & range & $0-6$ & $0-6$ & $0-7$ \\
& $\mathrm{n}$ & 37 & 46 & 50 \\
\hline N15 & mean & 2.47 & 3.07 & 3.33 \\
\hline \multirow{2}{*}{ Total } & range & $0-18$ & $0-39$ & $0-39$ \\
& $\mathrm{n}$ & 203 & 381 & 406 \\
\hline N30 & mean & 6.77 & 12.70 & 13.53 \\
\hline
\end{tabular}

The values in males groups with higher and lower caries prevalence were found significantly different in DFT clin $(p=0.001)$. DFS clin $(p=0.005)$ and DFS RDG $(p=0.004)$.

The values in females groups with higher and lower caries prevalence were found significantly different in DFT clin $(\mathrm{p}<$ 0.001). DFS clin. $(p<0.001)$ and DFS RDG $(p<0.001)$.

In groups with higher caries prevalence, males and females have comparable values: DFS clin 22.83 and $22.00(\mathrm{p}=0.627)$ and DFS RDG 24.50 and $23.00(\mathrm{p}=0.570)$.

In groups with lower caries prevalence, all values were higher in females: DFT clin 1.86 and 3.00. DFS clin 2.57 and 3.50 and DFS RDG 2.71 and 3.88.

\section{Discussion}

\section{Diagnostic methods}

With clinical examination by inspection it is not possible to check all initial carious lesions, mainly on proximal areas of teeth. Usage of interproximal radiographical projection (bitewing) reveals $30-50 \%$ more radiolucencies $(7,17,22,24)$.

In present study only a neglectible increment of structure changes was found. The observation consequently revealed not only visible defects and fillings, but also initial demineralization $(1,8,10)$.

\section{Dental caries indices DFT and DFS}

In individuals with low caries experience, the index DFT is similar to DFS, because one tooth usually bears one surface with decay or filling. Individuals with higher caries experience characteristically develop more defects without or with filling on one tooth. This is expressed in higher value of DFS $(6,12,17,23,24)$.

In present study, different values of DFT and DFS were found in total, as well as separately in males and females (Tab. 1). It is more expressed in higher caries prevalence group in comparison
Tab. 3. Dental caries indices in males groups with higher and lower caries prevalence.

\begin{tabular}{llccc}
\hline Groups & & DFT clin. & DFS clin. & DFS RDG \\
\hline Higher Prevalence & $\mathrm{n}$ & 69 & 137 & 147 \\
\hline N6 & mean & 11.50 & 22.83 & 24.50 \\
\hline Lower Prevalence & $\mathrm{n}$ & 13 & 18 & 19 \\
\hline N7 & mean & 1.86 & 2.57 & 2.71 \\
\hline Total & $\mathrm{n}$ & 82 & 155 & 166 \\
\hline N13 & mean & 6.31 & 11.92 & 12.77 \\
\hline
\end{tabular}

Tab. 4. Dental caries indices in females groups with higher and lower caries prevalence.

\begin{tabular}{llccc}
\hline Groups & & DFT clin. & DFS clin. & DFS RDG \\
\hline Higher & $\mathrm{n}$ & 97 & 198 & 209 \\
\hline N9 & mean & 10.78 & 22.00 & 23.22 \\
\hline Lower & $\mathrm{n}$ & 24 & 28 & 31 \\
\hline N8 & mean & 3.00 & 3.50 & 3.88 \\
\hline Total & $\mathrm{n}$ & 121 & 226 & 240 \\
\hline N17 & mean & 7.12 & 13.29 & 14.12 \\
\hline
\end{tabular}

with lower caries prevalence group in total (Tab. 2), as well as separately in males (Tab. 3) and females (Tab. 4).

A comparison of caries prevalence in medical students aged 1924 years

DFT in 20-year-old Prague students was found to be $4.95-$ $7.87(5)$.

DFT in 19-24-year-old Olomouc students was found to be 9.67-15.22 and 1.93-13.64 in males and females, respectively (13, 14). In Brno, the DFT was 6.54 and 9.03 in males and females, respectively (22).

In present study, the total DFT was 6.77 ; 6.31 in males and 7.12 in females. In 2011, the DFT values in Bratislava were similar or lower in all groups. In females, the caries prevalence was higher than in males.

More comparable are present results with previous study of Javorka et al (6) in similar sample of dentistry students aged 21-23 years in Bratislava. Authors evaluated also the DFS index.

The DFT index was found to be 11.53; 9.66 in males and 12.42 in females. The DFS index was found to be $16.06 ; 14.66$ in males and 19.68 in females. In present study, the DFS index was 12.70 , 11.92 in males and 13.29 in females.

In 1997, the values of DFT and DFS indices were higher in total, both in males and females. This is more comparable with values of higher caries prevalence group in 2011.

In females, the caries prevalence was higher than in males.

\section{Conclusions}

Dentistry students were the optimal sample to represent what is possible to achieve in the improvement of dental health in young individuals. Indices in the group with lower caries prevalence do not only give the information in sense of low range of values. Caries experience on one or few tooth surfaces and low difference between DFT and DFS indices shows the possibility for preserving tooth structures and preventing further consequences. 
The trend in modern dentistry lies in prevention of dental caries and non-invasive therapy $(18,21)$. This is possible only under well-timed diagnosis of initial stages of carious process and regular visiting the dentist $(11,16)$. Under dentist's professional guidance it is essential to follow the current preventive home-care means, namely diet, oral hygiene and remineralizing factors $(2,20)$.

\section{References}

1. Bürklein S. Diagnostika zubního kazu. Aktuální přehled současných možností. Progresdent 2010; 16 (3): 16-25.

2. Cerny R. Mineralized dental enamel matrix proteins. Bratisl Lek Listy 2010; 111 (5): 299-302.

3. Featherstone JD, Domjean S, Jenson L, Wolff M, Young DA. Caries Risk Assessment in Practice for Age 6 Through Adult. CDAJ 2007; 55 (10): 703-713.

4. Frankovič K. Potreba ošetrovania chrupu u dorastu. Prakt Zub Lék 1991; 39 (5-6): 134-139.

5. Gojišová E, Zemanová E. Epidemiologická studie orálního zdraví u skupiny pražských vysokoškolákủ. Prakt Zub Lék 1990; 38 (3): 77-85.

6. Javorka V, Heribanová A, Janková M, Tomandlová A. Výskyt kazu a stav jeho ošetrenia u poslucháčov stomatológie na Lekárskej fakulte UK v Bratislave. Stomatológ 1997; 7 (3): 12-15.

7. Kidd EAM, Pitts NB. A reappraisal of the value of the bitewing radiograph in the diagnosis of posterior approximal caries. Brit Dent J 1990; 164 (6): 195-200.

8. Koval'ová E, Javorka V. Vyšetrujeme pacientov dostatočne? Progresdent 2001; 7 (2): 8-12.

9. Kukletová M, Izakovičová Hollá L, Broukal Z, Musilová K, Kukla L. Vztah mezi ukazateli orálního zdraví u 13-15letých dětí skupiny ELSPAC Brno a stupněm vzdělání jejich rodičů. Čes Stomat 2013; 113 (1): 7-13.

10. Ležovič J et al. Detské zubné lekárstvo. Banská Bystrica: Dalli- BB, sro, 2012, 376.

11. Markovská N, Vidriczkóová Š, Tamášová M, Číčelová B, Bachárová N. Orálne zdravie v Slovenskej republike. Stomatológ 2003; 13 (1): 2-5.

12. Pavleová G, Veselá S. Stanovenie aktivity zubného kazu u detí a mladých jedincov v zubnej praxi. Lek Obzor 2012; 61 (2): 450-452.
13. Pavleová G, Veselá $\mathbf{S}$. Výsledky kultivácie kariogénnych mikroorganizmov v sline mladých jedincov. Lek Obzor 2013; 62 (6): 221-223.

14. Prošková J, Macháčková L, Doubravský V, Stejskalová J. Stav chrupu a hygieny dutiny ústní u studentů stomatologického směru v Olomouci. Prakt Zub Lék 1990; 38 (8): 232-236.

15. Prošková J, Macháčková L, Stejskalová J. Orální zdraví u studentů stomatologického směru LF UP v Olomouci v průbehu pětiletého studia. Čes Stomat 1995; 95 (1): 26-31.

16. Říha M, Lenčová E, Broukal Z. Kvalita zdravotní péče v České republice v kontextu Evropské unie. Prakt Zub Lék 2013; 61 (1): 15-19.

17. Ságlová S, Bednář $\mathbf{P}$, Černý $\mathbf{D}$. Aproximálny kaz a jeho výskyt u 18 letých stredoškoláků. Prakt Zub Lék 2003; 51 (5): 154-163.

18. Stefanovska E, Nakova M, Radojkova- Nikolovska V, Ristoska S. Tooth-brushing intervention programe among children with mental handicap. Bratisl Lek Listy 2010; 111 (5): 299-302.

19. Thurzo A, Stanko P, Urbanova W, Suchancova B, Makovnik M, Javorka V. The WEB 2.0 induced paradigm shift in the e-learning and the role of crowdsourcing in dental education. Bratisl Lek Listy 2010; 111 (3): 168-175.

20. Thurzo A, Javorka V, Stanko P, Suchancova B, Lehotska V, Valkovic L. Digital and manual cephalometric analysis. Bratisl Lek Listy 2010; 111 (2): 97-100.

21. Urbanova W, Kotova M, Vankova Z. The incidence of cleft lip and palate in the Czech Republic in 1994-2008. Bratisl Lek Listy 2013; 114 (8): 474-479.

22. Veselá S, Tomandlová A. Použitie náhryzových snímok pri hodnotení kazov a výplní. Stomatológ 2003; 13 (4): 28-29.

23. Veselá S, Pavleová G. Rizikové faktory a dynamika kazového procesu. Stomatológ 2008; 13 (3): 15-16.

24. Veselá S, Pavleová G, Tomandlová A, Baranovičová K. Hodnotenie aproximálnych kazov na snímkach v záhryze u mladých jedincov. Stomatológ 2011; 21 (1): 26-28.

25. Vinická M, Stř̌eštíková H, Novák A. Stav chrupu posluchačů stomatologického směru Lékařské fakulty UJEP v Brně ve škol. roce 1974/1975. Prakt. zub. Lék 1976; 24 (9): 271-276.

Received October 9, 2013. Accepted February 15, 2014. 